\title{
Fanconi Anemia, Complementation Group
} A

National Cancer Institute

\section{Source}

National Cancer Institute. Fanconi Anemia, Complementation Group A. NCI Thesaurus. Code C125702.

Fanconi anemia caused by mutations of the FANCA gene. FANCA gene mutations are the most common cause of Fanconi anemia. This gene provides instructions for making a protein that is involved in the Fanconi anemia (FA) pathway. 